Note

\section{Role of Gastrointestinal Microflora on Digestibility in Young Rats Fed Diets Containing Sodium Phytate}

\author{
Tsutomu Yoshida and Mitami OHKuBo \\ Department of Food and Nutrition, Tachikawa College \\ of Tokyo, Azuma-cho, Akishima 196, Japan
}

Received March 16, 1984

In the case of practical diets, the digestibility of nitrogenfree extract including starch and hemicelluloses was higher in conventional rabbits $^{1)}$ and mice ${ }^{2)}$ than in their germ free (GF) counterparts. Although it was suggested that the bacterial breakdown of dietary starch might have improved the digestibility of nitogen-free extract in conventional animals, there has been no comparison of the digestibility of starch between mammals with and without gut flora, except for a comparison ${ }^{3)}$ between conventionalized (CVZ) and limited flora rats in which no difference was found. Therefore, a comparative study on the digestibility of nitrogen-free extract was conducted with GF and $\mathrm{CVZ}$ rats fed on a purified diet containing only corn starch as a source of nitrogen-free extract. Our previous study ${ }^{4)}$ showed a higher digestibility of crude fat in mice fed on a diet including $5 \%$ sodium phytate than in those fed on a phytate-free diet. It is not known, however, whether there is a similar tendency in rats. In order to ascertain this, comparative observations on digestibility between rats fed on phytate-free and phytate-containing diets were also undertaken in this experiment.

Weanling inbred Fischer strain (F344/Yit) male rats were used. The GF groups were maintained in Trexler flexible isolators, and the CVZ group, which were obtained by orally inoculating the fresh cecal contents of conventional rats diluted with physiological saline solutions at 3 weeks of age, were kept in a clean room. The experiment was performed using two groups of six GF rats and six CVZ rats. In each group, three animals each were fed on diets with or without $1 \%$ sodium phytate (Sigma Chemical Co., U.S.A.). The rats were housed individually throughout the study in stainless steel cages with wiremesh floors at a temperature of $22 \pm 1{ }^{\circ} \mathrm{C}$ with exposure to $12 \mathrm{hr}$ of continuous lighting per day, and were provided with experimental diets and distilled deionized water $a d$ lib. from 4 weeks of age. The rats were given a phytate-free diet $(\mathrm{L}-488 \mathrm{FYCr} \text {, a modification of } \mathrm{L}-488 \mathrm{~F})^{4,5}$ ) or $1 \%$ phytate-containing diet (L-488FYCrPh) based on starchcasein with $1 \% \mathrm{Cr}_{2} \mathrm{O}_{3}$ (Table I). The diets were sterilized by $5 \mathrm{Mrad}$ of $\gamma$-irradiation with ${ }^{50} \mathrm{Co}$. The chemical compositions of the diets were shown in Table II.

Feed intake and body weight were measured for 2 weeks from 5 weeks of age (mean initial body weight $=81 \mathrm{~g}$, mean final body weight $=132 \mathrm{~g}$ ), and the feces and urine were collected daily. The feces were dried in an electric oven at $70^{\circ} \mathrm{C}$ after spraying with a $5 \% \mathrm{HCl}$ solution. The urine was collected in a collecting cylinder with a $5 \% \mathrm{HCl}$ solution.. The diets contained $1 \% \mathrm{Cr}_{2} \mathrm{O}_{3}$ for use as a marker, but complete collection of the feces was achieved and the samples were not analysed for Cr. The official methods of the A.O.A.C. ${ }^{6)}$ were used for determining the chemical compositions. The data were analyzed statistically by the analysis of variance, and the differences between the means were considered significant if $p<0.05$.

The apparent digestibilities of the dietary components in the four groups are presented in Table III. The comparison between two kinds of microbial status of the animals showed that in the CVZ groups the digestibility of

Table I. Composition of Experimental Diets

\begin{tabular}{lcc}
\hline & $\begin{array}{c}\text { L-488FYCr* } \\
(\mathrm{g} / 100 \mathrm{~g})\end{array}$ \\
\hline Casein & 24.0 & 24.0 \\
Corn starch $_{\text {Cellulose }^{a}}$ & 59.4 & 59.4 \\
DL-Methionine $_{\text {Corn oil }}{ }^{b}$ & 5.0 & 5.0 \\
myo-Inositol $_{\text {Vitamin mixture }^{c}}$ & 0.3 & 0.3 \\
Mineral mixture $^{d}$ & 5.0 & 5.0 \\
$\mathrm{Na}_{2} \mathrm{HPO}_{4}$ & 0.1 & 0.1 \\
$\mathrm{Sodium} \mathrm{phytate}^{e}$ & 0.5 & 0.5 \\
$\mathrm{Cr}_{2} \mathrm{O}_{3}$ & 3.7 & 3.7 \\
\hline
\end{tabular}

a Toyo filter paper for feed type No. D (40 60 mesh).

$b$ Corn oil : modification of Ladek-55=3:2. Modification of Ladek-55** containing $1,600 \mathrm{IU}$ of vitamin A (acetate + palmitate), $100 \mathrm{IU}$ of vitamin $\mathrm{D}_{3}, 47.5 \mathrm{mg}$ of $d l$ - $\alpha$-tocopheryl acetate, $10 \mathrm{mg}$ of vitamin $\mathrm{K}_{3}$, and corn oil to make $2 \mathrm{~g}$.

c Vitamin B mixture** contained $6 \mathrm{mg}$ of thiamine, $3 \mathrm{mg}$ of riboflavin, $5 \mathrm{mg}$ of nicotinamide, $30 \mathrm{mg}$ of calcium pantothenate, $200 \mathrm{mg}$ of choline chloride, $2 \mathrm{mg}$ of phyridoxine $\mathrm{HCl}, 0.4 \mathrm{mg}$ of pyridoxamine dihydrochloride, $0.1 \mathrm{mg}$ of biotin, $1 \mathrm{mg}$ of folic acid, $5 \mathrm{mg}$ of $p$-amino-benzoic acid, $25 \mathrm{mg}$ of trituration of $0.1 \%$ vitamin $\mathrm{B}_{12}$ in mannitol, and corn starch carrier to make $500 \mathrm{mg}$.

d Mineral mixture contained $515 \mathrm{mg}$ of iodized $\mathrm{NaCl}$, $400 \mathrm{mg}$ of $\mathrm{MgSO}_{4}, 60 \mathrm{mg}$ of $\mathrm{Fe}\left(\mathrm{C}_{6} \mathrm{H}_{5} \mathrm{O}_{7}\right)_{2}, 20 \mathrm{mg}$ of $\mathrm{MnCO}_{3}, 2.5 \mathrm{mg}$ of $\mathrm{CuO}, 2.5 \mathrm{mg}$ of $\mathrm{ZnO}, 0.05 \mathrm{mg}$ of $\mathrm{CoCl}_{2} \cdot 6 \mathrm{H}_{2} \mathrm{O}, 0.01 \mathrm{mg}$ of $\mathrm{NaF}, 0.003 \mathrm{mg}$ of $\mathrm{MoO}_{3}$, $0.01 \mathrm{mg}$ of $\mathrm{KBr}, 0.01 \mathrm{mg}$ of $\mathrm{Na}_{2} \mathrm{SeO}_{3}, 1,700 \mathrm{mg}$ of $\mathrm{CaCO}_{3}$, and $1,000 \mathrm{mg}$ of $\mathrm{K}_{2} \mathrm{HPO}_{4}$ (modification of B. S. Reddy et al.***).

e Sigma Chemical Co., U.S.A.

* Modification of $\mathrm{L}-488 \mathrm{~F}$. 4 )

** B. S. Reddy et al., J. Nutr., 97, 327 (1969).

*** B. S. Reddy et al., J. Nutr., 97, 353 (1969). 
Table II. Chemical Composition of Experimental Diets

$(\%$ on dry matter $)$

\begin{tabular}{ccccccc}
\hline Diet & $\begin{array}{c}\text { Organic } \\
\text { matter }\end{array}$ & $\begin{array}{c}\text { Crude } \\
\text { protein* }\end{array}$ & $\begin{array}{c}\text { Crude } \\
\text { fat }\end{array}$ & $\begin{array}{c}\text { Nitrogen-free } \\
\text { extract }\end{array}$ & $\begin{array}{c}\text { Crude } \\
\text { fiber }\end{array}$ & $\begin{array}{c}\text { Crude } \\
\text { ash }\end{array}$ \\
\hline $\begin{array}{c}\text { Phytate-free diet } \\
\text { (L-488FYCr) } \\
\begin{array}{c}\text { Phytate-containing diet } \\
\text { (L-488FYCrPh) }\end{array}\end{array}$ & 94.4 & 23.8 & 5.7 & 61.8 & 3.1 & 5.6 \\
\hline
\end{tabular}

* $\mathrm{N} \times 6,38$.

Table III. Apparent Digestibility of Diets ( $\%$ )

(means \pm standard deviations, $n=3$ )

\begin{tabular}{|c|c|c|c|c|c|c|c|}
\hline & $\begin{array}{c}\text { Dry } \\
\text { matter }\end{array}$ & $\begin{array}{l}\text { Organic } \\
\text { matter }\end{array}$ & $\begin{array}{l}\text { Crude } \\
\text { protein }\end{array}$ & $\begin{array}{l}\text { Crude } \\
\text { fat }\end{array}$ & $\begin{array}{c}\text { Nitrogen-free } \\
\text { extract }\end{array}$ & $\begin{array}{l}\text { Crude } \\
\text { fiber }\end{array}$ & $\begin{array}{l}\text { Crude } \\
\text { ash }\end{array}$ \\
\hline \multicolumn{8}{|l|}{ Germfree rats } \\
\hline Phytate-free diet & $90.5 \pm 0.3$ & $91.9 \pm 0.2$ & $92.8 \pm 0.4$ & $95.7 \pm 0.3$ & $95.1 \pm 0.3$ & $14.3 \pm 2.5$ & $71.5 \pm 4.3$ \\
\hline Phytate-containing diet & $90.7 \pm 0.2$ & $92.2 \pm 0.2$ & $93.4 \pm 0.4$ & $97.7 \pm 0.4$ & $95.0 \pm 0.1$ & $17.9 \pm 1.4$ & $64.9 \pm 1.0$ \\
\hline \multicolumn{8}{|l|}{ Conventionalized rats } \\
\hline Phytate-free diet & $90.8 \pm 0.3$ & $92.5 \pm 0.3$ & $93.3 \pm 0.2$ & $95.0 \pm 0.5$ & $96.1 \pm 0.4$ & $13.5 \pm 3.4$ & $62.3 \pm 1.2$ \\
\hline Phytate-containing diet & $90.6 \pm 0.2$ & $92.3 \pm 0.1$ & $93.6 \pm 0.4$ & $98.1 \pm 0.4$ & $95.4 \pm 0.1$ & $13.1 \pm 1.4$ & $59.1 \pm 1.6$ \\
\hline \multicolumn{8}{|l|}{ Statistical summary } \\
\hline Microbial status & - & $*$ & - & - & $* *$ & - & $* * *$ \\
\hline Phytate content & - & - & - & $* * *$ & $*$ & - & $* *$ \\
\hline Interaction & - & - & - & - & - & - & - \\
\hline
\end{tabular}

Significantly different at $* p<0.05, * * p<0.01,{ }^{* * *} p<0.001$.

organic matter was higher while that of crude ash was lower than in the GF groups. As a result, similar digestibilities of dietary dry matter between the GF and CVZ rats were obtained, and this tendency was the same as the observations of Corring et al. ${ }^{7)}$

Since the nitrogen-free extract content in this study was ca. $60 \%$, the higher digestibility of organic matter in $\mathrm{CVZ}$ rats was caused by the higher digestibility of the nitrogenfree extract. It is known that the presence of microflora is associated with a decrease of amylase activity in the intestinal contents of rat. ${ }^{8)}$ Therefore, the higher digestibility of the nitrogen-free extract in CVZ rats could be ascribed to the fact that starch granules are broken down more rapidly when surrounded by living bacteria than when merely suspended in amylase, ${ }^{9)}$ in addition to the hemicellulose breakdown by intestinal bacteria.

The digestibility of crude ash was lower in CVZ rats than in their GF counterparts. This coincides with the fact that lower digestibilities of such dietary minerals as $\mathrm{Ca}, \mathbf{P}$ and $\mathrm{Mg}$ were observed in conventional mice ${ }^{2)}$ and $\mathrm{CVZ}$ rats (unpublished data) than in GF animals.

Similar digestibilities of crude protein, crude fat and crude fiber were observed in both the GF and CVZ rats in the present experiment. These results did not agree with the data of Iwabuchi et al. ${ }^{3)}$ and Corring et al. ${ }^{7)}$ who found differences in the digestibilities of crude protein ${ }^{3,7)}$ and crude fat $^{3)}$ between adult GF and CVZ rats fed on purified diets. It is possible that this discrepancy may be due to the use of different ages of rats and/or different diets. However, our finding for crude fat is in accordance with the results of Demarne et al. ${ }^{10)}$ who observed no difference in the digestibility of total dietary lipids between GF and conventional rats fed on a purified diet. It was observed that purified diets ${ }^{4)}$ had much higher digestibility than practical diets. ${ }^{2)}$ In spite of the higher activities of proteases $^{8,11,12)}$ and lipase ${ }^{13)}$ in the intestinal contents of GF animals than their conventional counterparts, therefore, it seems that the beneficial effect on the digestibilities of crude protein and crude fat in GF rats is diminished when the rats are fed on a purified diet.

No difference in the digestibility of crude fiber was found between GF and CVZ rats, and the same result has already been obtained from growing mice. ${ }^{2)}$ Since the cellulase activity of the gut contents was found only in conventional animals and not in GF animals, ${ }^{12)}$ it might be possible that a disappearance of part of the crude fiber into the enlarged cecum of growing GF animals occurred. The facts, that the fecal lignin excretion exceeded the 
lignin intake in human subjects ${ }^{14)}$ and that measurable quantities of non-cellulosic fiber were found in the feces of animals fed on diets free of any fiber supplement except $1 \%$ cellulose ${ }^{15)}$ suggests that crude fiber derived from intestinal microflora may be present at appreciable levels in CVZ feces. In spite of the additional fiber components of microbial origin in the CVZ feces, no difference was obtained between the digestibilities of crude fiber in GF and CVZ rats as mentioned above. Therefore, it is probable that there was a higher digestibility of dietary cellulose in CVZ rats than in GF rats. It is expected that further comparative studies between GF and CVZ rats will be directed towards differentiating the abilities to digest dietary fiber components including cellulose, hemicelluloses, pectins and lignin.

The digestibilities of dry matter, organic matter, crude protein and crude fiber were unaffected by the presense or absence of phytate in diets (Table I). On the other hand, a higher digestibility of crude fat and lower digestibilities of nitrogen-free extract and crude ash were found in rats fed on phytate-containing diet when compared with the controls fed on phytate-free diet. This observation concerning crude fat digestion is in accordance with our previous experiment on mice, ${ }^{4)}$ in which the $5 \%$ phytate-containing diet group showed a higher digestibility for crude fat than the phytate-free diet group. It is known that fatty acid leaves the micelles and forms insoluble $\mathrm{Ca}$ soaps when $\mathrm{Ca}$ ions are added to a micellar solution of the fatty acid in bile salt. ${ }^{16)}$ It has also been observed that $\mathrm{Ca}$ in the diet can bind tightly with phytic acid. ${ }^{17,18)}$ Therefore, in the intestines there is a possibility that fewer $\mathrm{Ca}$ ions are free and fewer $\mathrm{Ca}$ soaps of fatty acids, which are insoluble and unabsorbable, are formed in rats fed on phytatecontaining diet than in rats fet on phytate-free diet.

Several researchers ${ }^{19 \sim 21)}$ have observed that phytate is a potent inhibitor of amylases from different origins, and in vitro digestion studies involving human saliva ${ }^{22}$ ) have shown that the rate of digestion of raw wheat starch was reduced by $50 \%$ in the presence of phytate. This inhibition by phytate is likely to affect the digestion of starch which was the sole nitrogen-free extract source in the present experimental diet. In mice ${ }^{2)}$ and rats (unpublished data) fed on purified diets, we found a lower tendency for digestibilities of $\mathrm{Ca}$ and $\mathrm{P}$ in animals fed on the phytatefree diet. Therefore, it is probable that the phytatecontaining group has a lower digestibility for crude ash.

Although it was speculated that phytate hydrolysis might be affected by the presence or absence of gut flora and, thus, that a comparison of the digestibilities of groups fed on phytate-free and phytate-containing diets might show different tendencies between GF and CVZ rats, no interactions concerning the microbial status and the phytate content were found for the digestibilities of dietary components including crude ash (Table III). Therefore, further comparative studies between GF and $\mathrm{CVZ}$ rats on the digestibility of dietary minerals are in progress.

In conclusion, the nutrient digestibilities of the purified diets were affected by the presence of gut flora and dietary phytate, i.e., higher digestibilities of organic matter and nitrogen-free extract (starch) and lower for crude ash in CVZ rats than in GF rats, and higher digestibility of crude fat and lower for nitrogen-free extract and crude ash in. rats fed on a $1 \%$ phytate diet than in rats fed on a phytatefree diet.

Acknowledgments. We are grateful to Dr. M. Mutai, Mr. A. Iwabuchi, Mrs. K. Makino and Miss M. Kato of the Yakult Central Institute for Microbiological Research for the preparation of diets and care of the animals.

\section{REFERENCES}

1) T. Yoshida, J. R. Pleasants, B. S. Reddy and B. S. Wostmann, Br. J. Nutr., 22, 723 (1968).

2) T. Yoshida and S. Shinoda, Agric. Biol. Chem., 46, 561 (1982).

3) A. Iwabuchi, T. Takahashi, M. Mutai and M. Kandatsu, Eiyo to Shokuryo (J. Jpn. Soc. Food Nutr.), 30, 141 (1977).

4) T. Yoshida, S. Shinoda, T. Matsumoto and S. Watarai, J. Nutr. Sci. Vitaminol., 28, 401 (1982).

5) B. S. Wostmann, E. Bruckner-Kardoss, M. Beaver, L. Chang and D. Madsen, J. Nutr., 106, 1782 (1976).

6) Association of Official Analytical Chemists, "Official Methods of Analysis of the A.O.A.C," 12th Ed., A.O.A.C., Washington, D.C., 1975, pp. $129 \sim 146$.

7) T. Corring, C. Moreau and R. Ducluzeau, Am. J. Clin. Nutr., 32, 1231 (1979).

8) B. S. Reddy, J. R. Pleasants and B. S. Wostmann, J. Nutr., 97, 327 (1969).

9) F. Baker, H. Nasr, F. Morrice and J. Bruce, J. Path. Bact., 62, 617 (1950).

10) Y. Demarne, T. Corring, A. Pihet and E. Sacquet, Gut, 23, 49 (1982).

11) M. E. Coates, "Clinical and Experimental Gnotobiotics (Zbl. Bakt. Suppl. 7)”, ed. by T. Fliedner, H. Heit, D. Neithammer and H. Pflieger, Gustav Fischer Verlag, Stuttgart and New York, N.Y., 1979, pp. $29 \sim 37$.

12) N.-C. Juhr, Z. Versuchstierk., 22, 197 (1980).

13) Y. Kawai, N. Suegara and K. Yazawa, Mechan. Ageing Develop., 16, 149 (1981).

14) D. A. T. Southgate, W. J. Branch, M. J. Hill, B. S. Drasar, R. L. Walters, P. S. Davies and I. McLean Baird, Metabolism, 25, 1129 (1976).

15) V. F. Rasper, J. M. Brillouet, D. Bertrand and C. Mercier, J. Food Sci., 46, 559 (1981).

16) A. F. Hofmann, "Proceedings of 6th International Congress of Nutrition, 1963," E. \& S., Livingstone Ltd., Edinburgh and London, 1964, p. 501.

17) K. Subba Rao and B. S. Narasinga Rao, Nutr. Rep. Int., 28, 771 (1983).

18) E. Graf, J. Agric. Food Chem., 31, 851 (1983). 
19) R. W. Cawley and T. A. Mitchell, J. Sci. Food Agric., 21) T. Jacobsen and D. Slotfeldt-Ellingsen, Cereal
19, 106 (1968).

20) C. B. Sharma, M. Goel and M. Irshad, 22) J. H. Yoon, L. U. Thompson and D. J. Jenkins, $A m$. Phytochemistry, 17, 201 (1978). $\quad$ J. Clin. Nutr., 38, 835 (1983). 